\title{
zoOSy/stena
}

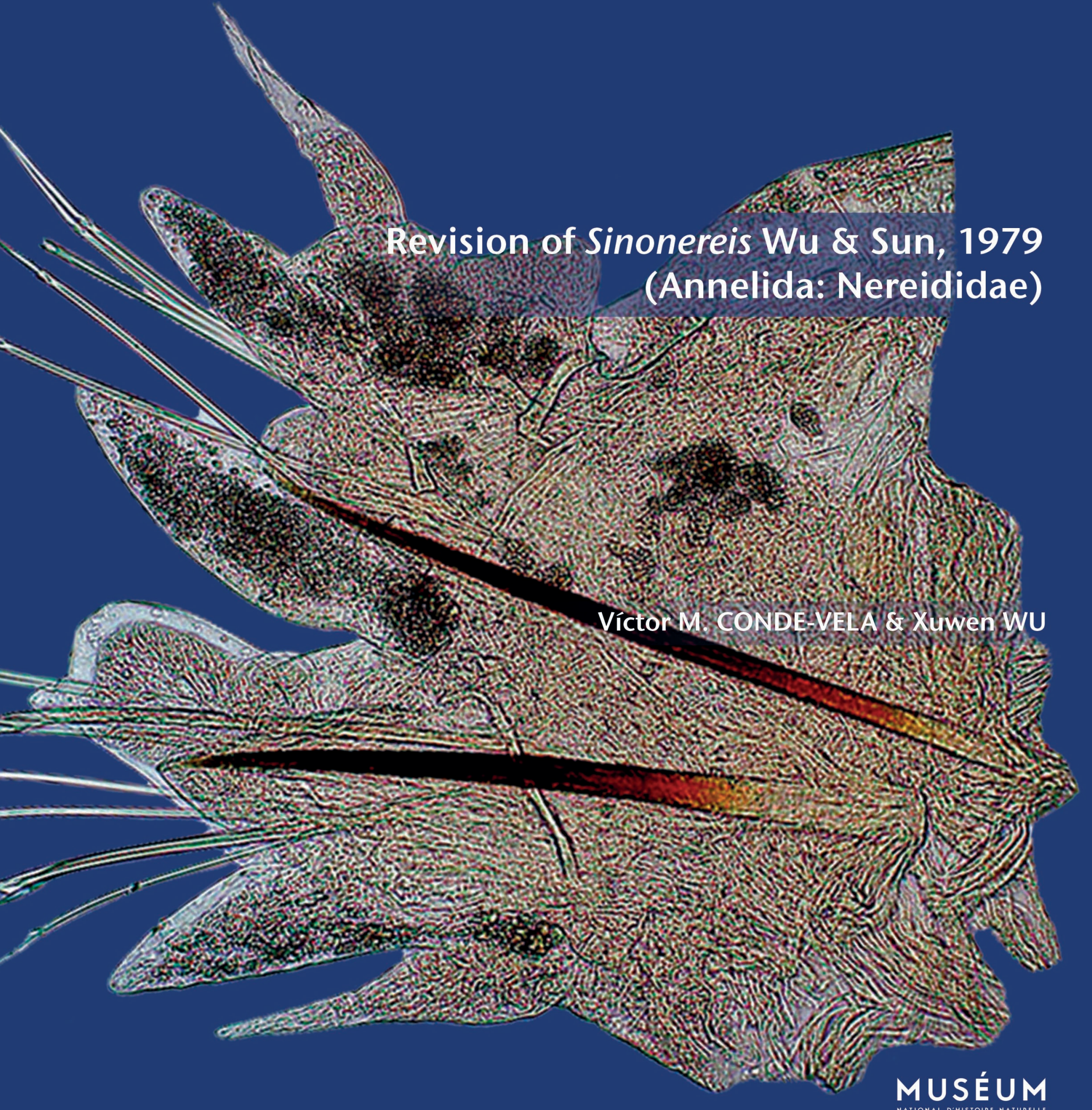


DiRECTEUR DE LA PUBlication: Bruno David

Président du Muséum national d'Histoire naturelle

RÉDACTRICE EN CHEF / EDITOR-IN-CHIEF: Laure Desutter-Grandcolas

AssistanTS DE RÉDACTION / AsSISTANT EDITORS: Anne Mabille (zoosyst@mnhn.fr), Emmanuel Côtez

Mise en page / Page Layout: Anne Mabille

COMITÉ SCIENTIFIQUE / SCIENTIFIC BOARD:

James Carpenter (AMNH, New York, États-Unis)

Maria Marta Cigliano (Museo de La Plata, La Plata, Argentine)

Henrik Enghoff (NHMD, Copenhague, Danemark)

Rafael Marquez (CSIC, Madrid, Espagne)

Peter Ng (University of Singapore)

Norman I. Platnick (AMNH, New York, États-Unis)

Jean-Yves Rasplus (INRA, Montferrier-sur-Lez, France)

Jean-François Silvain (IRD, Gif-sur-Yvette, France)

Wanda M. Weiner (Polish Academy of Sciences, Cracovie, Pologne)

John Wenzel (The Ohio State University, Columbus, États-Unis)

COUVERTURE / COVER:

Chaetiger 35, right parapodium of Sinonereis heteropoda Wu \& Sun, 1979 paratype.

Zoosystema est indexé dans / Zoosystema is indexed in:

- Science Citation Index Expanded (SciSearch ${ }^{\circledR}$ )

- ISI Alerting Services ${ }^{\circledR}$

- Current Contents ${ }^{\circledR}$ / Agriculture, Biology, and Environmental Sciences ${ }^{\circledR}$

- Scopus ${ }^{\circledR}$

Zoosystema est distribué en version électronique par / Zoosystema is distributed electronically by:

- BioOne ${ }^{\circledR}$ (http://www.bioone.org)

Les articles ainsi que les nouveautés nomenclaturales publiés dans Zoosystema sont référencés par / Articles and nomenclatural novelties published in Zoosystema are referenced by:

- ZooBank ${ }^{\circledR}$ (http://zoobank.org)

Zoosystema est une revue en flux continu publiée par les Publications scientifiques du Muséum, Paris / Zoosystema is a fast track journal published by the Museum Science Press, Paris

Les Publications scientifiques du Muséum publient aussi / The Museum Science Press also publish:

Adansonia, Geodiversitas, Anthropozoologica, European Journal of Taxonomy, Naturae, Cryptogamie sous-sections Algologie, Bryologie, Mycologie.

Diffusion - Publications scientifiques Muséum national d'Histoire naturelle

CP 41 - 57 rue Cuvier F-75231 Paris cedex 05 (France)

Tél. : 33 (0)1 40794805 / Fax: 33 (0)1 40793840

diff.pub@mnhn.fr / http://sciencepress.mnhn.fr

(C) Publications scientifiques du Muséum national d'Histoire naturelle, Paris, 2019

ISSN (imprimé / print): 1280-9551/ ISSN (électronique / electronic): 1638-9387 


\section{Revision of Sinonereis Wu \& Sun, 1979 (Annelida: Nereididae)}

Víctor M. CONDE-VELA

El Colegio de la Frontera Sur, Departamento de Ecología Acuática,

Chetumal, Quintana Roo 77010 (Mexico)

victorconde2323@gmail.com (corresponding author)

Xuwen WU

Department of Marine Organism Taxonomy and Phylogeny, Institute of Oceanology, Chinese Academy of Sciences, Qingdao 266071 (China)

wxwelegent@sina.com

Submitted on 7 May 2018 | Accepted on 6 August 2018| Published on 16 April 2019

Conde-Vela M. V. \& Wu X. 2019. - Revision of Sinonereis Wu \& Sun, 1979 (Annelida: Nereididae). Zoosystema 41 (9): 153-161. https://doi.org/10.5252/zoosystema2019v4a9. http://zoosystema.com/41/9

\section{ABSTRACT}

The genus Sinonereis Wu \& Sun, 1979 and the species Sinonereis heteropoda Wu \& Sun, 1979 were described from Chinese waters, based on only epitokous specimens with modified dorsal cirri in chaetigers 5-7 and bare pharynx. In the same publication, another species based on only atokes was described, Nicon sinica Wu \& Sun, 1979. We show that $N$. sinica is a junior synonym of S. heteropoda based on their affinities in chaetal and parapodial features. We redefine Sinonereis and formally synonymize $N$. sinica and S. heteropoda. Sinonereis closely resembles Nicon Kinberg, 1865 and Kainonereis modified dorsal cirri,

Nereididae, epitoky, Chamberlin, 1919, but Sinonereis differs from them by having napiform dorsal cirri in chaetigers 5-7, and by lacking notopodial dorsal ligules in chaetiger 3 in both atokes and epitokes.

\section{RÉSUMÉ}

Révision de Sinonereis Wu \& Sun, 1979 (Annelida: Nereididae).

Le genre Sinonereis Wu \& Sun, 1979 et l'espèce Sinonereis heteropoda Wu \& Sun, 1979 ont été décrits des eaux chinoises, seulement à partir de spécimens épitoques avec des cirres dorsaux modifiés sur les sétigères 5-7 et avec un pharynx nu. Dans la même publication, une autre espèce a été décrite à

MOTS CLÉS

Nereididae, cirres dorsaux modifiés, épitoquie,

dimorphisme sexuel, polychètes, partir d'atoques uniquement, Nicon sinica Wu \& Sun, 1979. Nous montrons ici que $N$. sinica est un synonyme junior de $S$. heteropoda basé sur leurs affinités pour les caractères des soies et des parapodes. Nous redefinissons Sinonereis et nous confirmons la synonyie entre $N$. sinica et $S$. heteropoda. Sinonereis ressemble fortement à Nicon Kinberg, 1865 et Kainonereis Chamberlin, 1919, mais Sinonereis s'en distingue par ses cirres dorsaux napiformes sur les sétigères 5-7, et par l'absence de languettes dorsales sur le sétigère 3, aussi bien chez les atoques que chez les épitoques. 


\section{INTRODUCTION}

Epitoky in nereidids consists in several morphological and physiological changes for a short pelagic life for reproduction, where the modified adults or epitokes swim and release their gametes in the water column; the unmodified individuals prior the sexual maturity are called atokes (Clark 1961; Schroeder \& Hermans 1975). The morphological modification often involves changes in parapodial, chaetal and sometimes pharyngeal ornamentation morphology. The linking of the atokes or non-reproductive stage with their respective epitokes of the same species is often difficult. Some genera have been established based on epitokes only because the epitokal modifications are very distinctive, but since the atoke morphology is not known, it is possible that some atoke-based species in different genera are actually the non-reproductive stage of another epitoke-based species; hence the importance of studying both epitoke and atoke morphology of known species (Conde-Vela et al. 2018).

The finding of some nereidid epitokes showing a unique combination of morphological features prompted Wu \& Sun $(1979: 95,96)$ to propose a new genus, Sinonereis to include a new species, $S$. heteropoda. The morphological features were that the pharynx had no papillae nor paragnaths, and that dorsal cirri of chaetigers 5-7 were modified as a "bulbous base and styliform terminal end". In the same publication, Wu \& Sun (1979) also recorded Nicon Kinberg, 1865 in China seas, and described another new species $N$. sinica based on several atokous specimens. Both species are very similar because they share the same characters of pharynx and chaetae as well as the same distribution range, and the main difference lies in the modified dorsal cirri in chaetigers 5-7 which are absent in $N$. sinica.

Subsequently, Miura (1990) recorded Nicon sinica in Japanese waters and found the species exhibit well-defined sexual dimorphism based on a number of specimens selected from a single sample. Males had dorsal cirri modified and neuropodial postchaetal lobes, matching the description of $S$. heteropoda, whereas females and immatures, showing no heteronereid transformations, were readily recognized as $N$. sinica. Miura (1990) concluded that the two species might belong to different stages of a single species, but he preferred to retain both species as valid instead of elucidating the synonymous status due to the unavailability of the type material.

Sinonereis closely resembles Kainonereis Chamberlin, 1919 because they both have a bare pharynx as well as modified dorsal cirri along chaetigers 5-7, but their affinities have not been assessed, mainly because the latter had not been revised until quite recently (Conde-Vela et al. 2018). In this contribution, we redescribe $S$. heteropoda based on the type material. Also, the synonymy of N. sinica with $S$. heteropoda is addressed, and the relationship between Sinonereis and Kainonereis, and also other similar genera, is discussed.

\section{MATERIAL AND METHODS}

Type materials of Sinonereis heteropoda and Nicon sinica are deposited in the collections of the Marine Biological Museum, Chinese Academy of Sciences (MBMCAS). Specimens were examined using a Zeiss Stemi SV 11 Apo stereomicroscope; to observe parapodial features and chaetae, some parapodia were removed and mounted in semi-permanent slides with ethanol-glycerol to be observed under a Zeiss Axiostar plus compound microscope. All parapodia are in anterior view. Photographs were taken with an AxioCam MRc5 digital camera with an adaptor.

The terminology follows Bakken \& Wilson (2005) to describe parapodia for atokes, and Conde-Vela et al. (2018) for epitokes. The terms 'achaetous ring' and 'anterior cirri' were used instead of 'peristomium' and 'tentacular cirri', respectively, as suggested by Santos et al. (2005).

\section{SYSTEMATICS}

Order PHYLLODOCIDA Dales, 1962

Family NEREIDIDAE de Blainville, 1818

\section{Genus Sinonereis Wu \& Sun, 1979}

Sinonereis Wu \& Sun, 1979: 95.

TYPE SPECIES. — Sinonereis heteropoda Wu \& Sun, 1979, by original designation.

Distribution. - The only species, Sinonereis heteropoda, is distributed along Eastern Asian coasts (Yellow Sea to eastern Japan). The genus has been signaled from the Atlantic Ocean but these records deserve confirmation.

Diagnosis (emended, new features highlighted in boldface). Prostomium with entire anterior margin. Four pairs of anterior cirri. Pharynx surface smooth. Upper notopodial ligule present from chaetiger 4 in atokes and epitokes. Notopodial prechaetal lobe present throughout body. In males, chaetigers 5 to 7 with napiform dorsal cirri (i.e., cirrophores globose or ovoid, cirrostyles cirriform); parapodia of natatory region with four lamellar processes (dorsal lamella, ventral lamella, upper and lower lamellae of ventral cirri); females without heteronereid transformation. Notochaetae homogomph spinigers; neurochaetae homogomph spinigers and heterogomph falcigers in supra-acicular fascicles, heterogomph spinigers and falcigers in sub-acicular fascicles.

\section{REMARKS}

The original diagnosis by Wu \& Sun (1979) focused in the presence of dorsal cirri with 'inflated' cirrophores in anterior chaetigers. Relevant features included in the new diagnosis are the presence of notopodial prechaetal lobes throughout the body, the presence of dorsal lobes in natatory chaetigers, the occurrence of notopodial dorsal ligules from chaetiger 4 in both atokes and epitokes (instead of 3 as usual in most nereidids), and the lack of heteronereid transformation in females. Other key features are the lack of both upper and lower lamellae (usually upper or both lamellae are present) and crenulations in dorsal cirri of natatory chaetigers. 

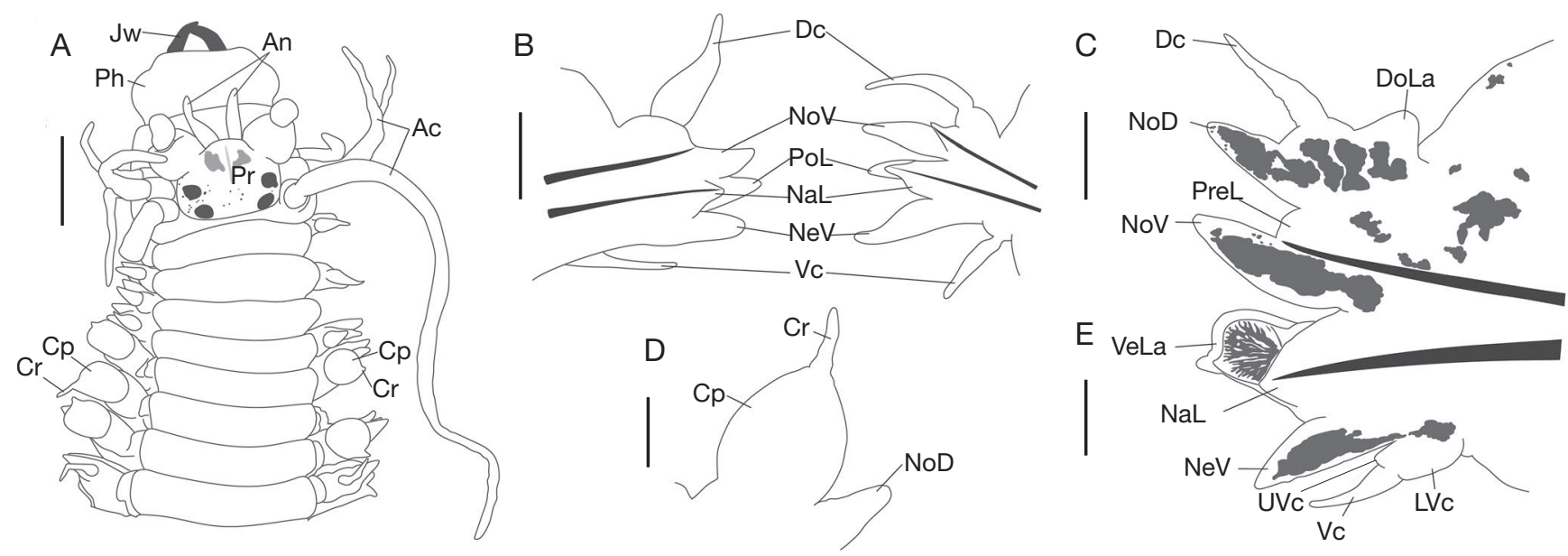

FIG. 1. - Morphology of Sinonereis Wu \& Sun, 1979 species: A, anterior end; B, chaetiger 3 of a male, anterior view; C, chaetiger 3 of a female, anterior view; D, napiform dorsal cirrus from mounted parapodium 6, anterior view; E, parapodium 35, anterior view. Abbreviations: Ac, anterior cirri; An, antennae; Cp, cirrophore; Cr, cirrostyle; Dc, dorsal cirrus; DoLa, dorsal lamellae; Jw, jaws; LVc, lower lamella of ventral cirrus; NaL, neuroacicular ligule; NeV, neuropodial ventral ligule; NoD, notopodial dorsal ligule; NoV, notopodial ventral ligule; Ph, pharynx; PoL, postchaetal lobe; Pr, prostomium; PreL, prechaetal lobe; UVc, upper lamella of ventral cirrus; Vc, ventral cirrus; VeLa, ventral lamella. A, D, E from paratype (MBMCAS A-37); B, redrawn from Wu \& Sun (1979: fig. 1c); C, redrawn from Miura (1990: fig. 1f). All chaetae omitted.

Wu et al. (1985) placed Sinonereis into the subfamily Nereidinae based on the presence of biramous parapodia, a small number of chaetae in the first chaetigers, and single ventral cirrus in all chaetigers (Wu et al. 1985: 44). Later, Sun \& Yang (2004) placed Sinonereis in the subfamily Gymnonereidinae sensu Fitzhugh (1987) because of the lack of paragnaths in pharynx, and the presence of biramous parapodia.

In the phylogenetic analysis by Santos et al. (2005), Sinonereis has an uncertain subfamily condition, a similar condition for several other genera. In their cladograms, Sinonereis appeared in a clade together with Leptonereis Kinberg, 1865, Tylonereis Fauvel, 1911 and Tylorrhynchus Grube, 1866 (Santos et al. 2005: figs 7, 8). This clade was supported by the character of enlarged notopodial dorsal ligules (in posterior chaetigers) (Santos et al. 2005), which match with Leptonereis, Tylonereis, and Tylorrhynchus, but not with Sinonereis. Sinonereis resembles Tylonereis and Tylorrhynchus by having neuropodial falcigers but separated from them by having basally expanded dorsal cirri, and unilobated neuropodial postchaetal lobes (Santos et al. 2005); additional differences with these genera are the presence of pharyngeal papillae and compound spinigers only in Tylonereis, and lack of both notopodial dorsal ligules and neuropodial ventral ligules in Tylorrhynchus, whereas Sinonereis species have no papillae in pharynx, have both compound falcigers and spinigers, and both notopodial dorsal ligules and neuropodial ventral ligules.

\section{Sinonereis heteropoda Wu \& Sun, 1979}

(Figs 1-3)

Sinonereis heteropoda Wu \& Sun, 1979: 96, figs 1a-j, 2a-d. - Wu et al. 1985: 52-54, figs 1A-J, 2A-D. — Sun \& Yang 2004: 80-82, fig. 3 A-N.
Nicon sinica Wu \& Sun, 1979: 99-101, fig. 3a-j, n. syn. - Wu et al. 1985: 60-61, fig. 3 A-J. — Miura 1990: 11-14, figs 1a-i, 2a-j. Paik 1997: 154, fig. 2a-j. — Sun \& Yang 2004: 79-80, fig. 3 A-J.

Type material of S. HeTEROPODA. - Holotype. China, Yellow Sea, MBMCAS A-36, o", R/V Handan, collection No. H0038-28, St. $3031\left(36^{\circ} 00 \mathrm{~N}, 121^{\circ} 00 \mathrm{E}\right), 30 \mathrm{~m}$, mud and gravel, 27.I.1959. Paratypes. China, East China Sea. MBMCAS A-37 (1), ơ, R/V 401, Collection No. D14 B-1, St. 4083 (2800N, 12330E), 90 m, fine brown sand, 8.XII.1959. - China, South China Sea. MBMCAS A-38 (1), o", R/V 101, collection No. N19 B-19, St. 6060 (22 00N, $\left.113^{\circ} 36 \mathrm{E}\right), 93 \mathrm{~m}$, mud and sand, 7.V.1960.

Type material of N. SiniCA. - Holotype. China, Yellow Sea, MBMCAS A-39, R/V Yancheng, collection No. Y28 B-5B, St. 3031, $29 \mathrm{~m}$, brown sand and gravel, 13.VI.1959. - Paratype. China, South China Sea. MBMCAS A-41 (1), R/V Hanggong, collection No. K6 B-4, St. $079\left(20^{\circ} 00 \mathrm{~N}, 113^{\circ} 00 \mathrm{E}\right), 117 \mathrm{~m}$, mud and sand, 11.VII.1959.

Distribution. - Yellow Sea; East China Sea; South China Sea; Pacific Ocean off Honsu, Japan.

\section{DESCRIPTION OF EPITOKE \\ Body}

Holotype of Sinonereis heteropoda (MBMCAS A-36) male, complete with 60 chaetigers, $12.6 \mathrm{~mm}$ long, $1.5 \mathrm{~mm}$ wide at chaetiger 10 (including parapodia); paratype (MBMCAS A-37) male, complete with 60 chaetigers, fragmented into two parts, anal cirri missing, $12.5 \mathrm{~mm}$ long, $1.5 \mathrm{~mm}$ wide at chaetiger 10 . Body yellowish, tapering posteriorly, pigmentation absent (Fig. 2A-C); whitish bundles of sperm in coelom present.

\section{Anterior end}

Prostomium ovate, wider than long; two independent antennae, half as long as prostomium; palps biarticulated, as long as antennae; eyes black, ovate to reniform, subequal (Figs 1A; $2 \mathrm{~A}, \mathrm{~B})$. Achaetous ring twice longer than first chaetiger; anterior cirri smooth, posterodorsal one reaching chaetiger 14 
(Figs 1A, 2A). Jaws transparent, brownish, dentate, each jaw with 7-8 teeth (Fig. 2D-E); pharynx smooth (Figs 1A; 2D, E).

\section{Chaetigers}

Body divided into non-natatory and natatory regions. Nonnatatory region subdivided in three subregions: a) chaetigers 1-4 with dorsal cirri fusiform and ventral cirri cirriform; b) chaetigers 5-7 with dorsal cirri napiform and ventral cirri fusiform; and c) chaetigers 8-21 with both dorsal and ventral cirri cirriform. Natatory region from chaetiger 22 to end of body.

First two chaetigers with neuroaciculae only, following chaetigers with both noto- and neuroaciculae. In chaetiger 1 , dorsal cirrus cirriform, 1.5 times longer than dorsal ligule. Dorsal ligule digitiform, twice as long as neuroacicular ligule. Neuroacicular ligule subconical; postchaetal lobe digitate, 1.5 times longer than neuroacicular ligule; neuropodial ventral ligule digitate, as long as dorsal ligule. Ventral cirrus cirriform, half as long as neuropodial ventral ligule.

In chaetiger 3 (Fig. 1B), dorsal cirrus fusiform (i.e., cirrophore slightly swollen, cirrostyle distinct), two times as long as notopodial ventral ligule. Notopodial dorsal ligule absent; prechaetal lobe inconspicuous; notopodial ventral ligule digitate, as long as neuropodial postchaetal lobe. Neuroacicular ligule subconical, half as long as postchaetal lobe; postchaetal lobe digitate; neuropodial ventral ligule digitate, as long as postchaetal lobe. Ventral cirrus cirriform, half as long as neuropodial ventral ligule.

In chaetigers 5-7 (Fig. 2H, I), dorsal cirrus with cirrophore globose or ovoid, cirrostyle cirriform. Notopodial dorsal ligule digitate, half as long as dorsal cirrus, as long as notopodial ventral ligule; prechaetal lobe rounded, very small; notopodial ventral ligule digitate, twice longer than neuroacicular ligule. Neuroacicular ligule subconical; postchaetal lobe digitate, slightly longer than neuroacicular ligule; neuropodial ventral ligule digitate, as long as neuroacicular ligule. Ventral cirrus fusiform, 0.8 times as long as neuropodial ventral ligule.

In chaetigers 8-21, dorsal and ventral cirri slender, cirriform. Notopodial and neuropodial ligules similar as in chaetigers 5-7.

Chaetigers from 22 to end of body modified (Fig. 2J-K). Dorsal cirrus with cirrophore slightly swollen, cirrostyle cirriform, 1.3 times length of notopodial dorsal ligule, becoming as the same length toward posterior chaetigers; dorsal lamella twice larger than cirrophore of dorsal cirrus. Notopodial dorsal ligules subconical, as long as notopodial ventral ligule; prechaetal lobe rounded, small; notopodial ventral ligule subconical or digitate, twice as long as neuroacicular ligule. Neuroacicular ligule subconical; postchaetal lobe expanded, lamellar, as long as and as wide as neuroacicular ligule, becoming shorter toward posterior chaetigers, tip with a small apex; neuropodial ventral ligule digitate, twice as long as neuroacicular ligule. Ventral cirrus cirriform, 0.8 times as long as neuropodial ventral ligule, with two small basal lamellae, becoming inconspicuous toward posterior chaetigers.

\section{Chaetae}

Notochaetae homogomph spinigers. Neurochaetae homogomph spinigers and heterogomph falcigers in supraacicular fascicles (Fig. 2F); heterogomph spinigers and falcigers in sub-acicular fascicles (Fig. 2G). Natatory chaetae absent.

Notopodial and neuropodial homogomph spinigers pectinate, teeth decreasing in size toward distal end; neuropodial heterogomph spinigers pectinate, teeth decreasing in size toward distal end, blade shorter than homogomph ones (Fig. 2F, G). Neuropodial heterogomph falcigers pectinate, teeth minute, distal tooth stout, incurved, with a distal tendon, both supra- and sub-acicular falcigers similar in size and shape in the same chaetiger; blades of falcigers increasing in size, teeth increasing in number, and size of both distal tooth and tendons decreasing in size, toward posterior chaetigers (Fig. 2F, G).

\section{Posterior end}

Pygidium tripartite; anal cirri cirriform, as long as last eight chaetigers (Fig. 2A, insert).

\section{DESCRIPTION ATOKE}

Body

Holotype of Nicon sinica (A-39) atoke specimen with 51 chaetigers, $11.5 \mathrm{~mm}$ long, $1.2 \mathrm{~mm}$ wide at chaetiger 10; paratype (A-41) immature with 48 chaetigers, $12 \mathrm{~mm}$ long, $1.4 \mathrm{~mm}$ wide at chaetiger 10 . Body yellowish, tapering posteriorly; brown pigment spots in prostomium and palps, brown spots in anterior margin of anterior chaetigers aligned in a band, fading in most-posterior chaetigers. Glandular masses brown at the base of dorsal cirri, both notopodial dorsal and ventral ligules, and neuropodial ventral ligules, in first third of body, enhancing toward posterior chaetigers; glandular masses in neuropodial ventral ligules disappearing toward posterior chaetigers.

\section{Anterior end}

Prostomium subpyriform, as long as wide; two independent antennae, half as long as prostomium; palps biarticulated, as long as antennae; eyes black, rounded, subequal (Fig. 3A, $\mathrm{B})$. Achaetous ring twice longer than first chaetiger; anterior cirri smooth, posterodorsal one reaching chaetiger 14 (Fig. 3A-C). Jaws dentate, each with 6-7 teeth; pharynx bare (Fig. 3E).

\section{Chaetigers}

First two chaetigers with neuroacicula only, following ones with both noto- and neuroaciculae. In chaetiger 3 (Fig. $3 \mathrm{H}$ ), dorsal cirri cirriform, 1.5 times longer than dorsal ligule. Notopodial dorsal ligule absent; prechaetal lobe inconspicuous; notopodial ventral ligule digitate, 1.5 times longer than neuroacicular ligule. Neuroacicular ligule digitate, twice longer than postchaetal lobe; postchaetal lobe subconical, half as long as neuropodial ventral ligule; neuropodial ventral ligule digitate. Ventral cirrus cirriform, 0.6 times as long as neuropodial ventral ligule. 

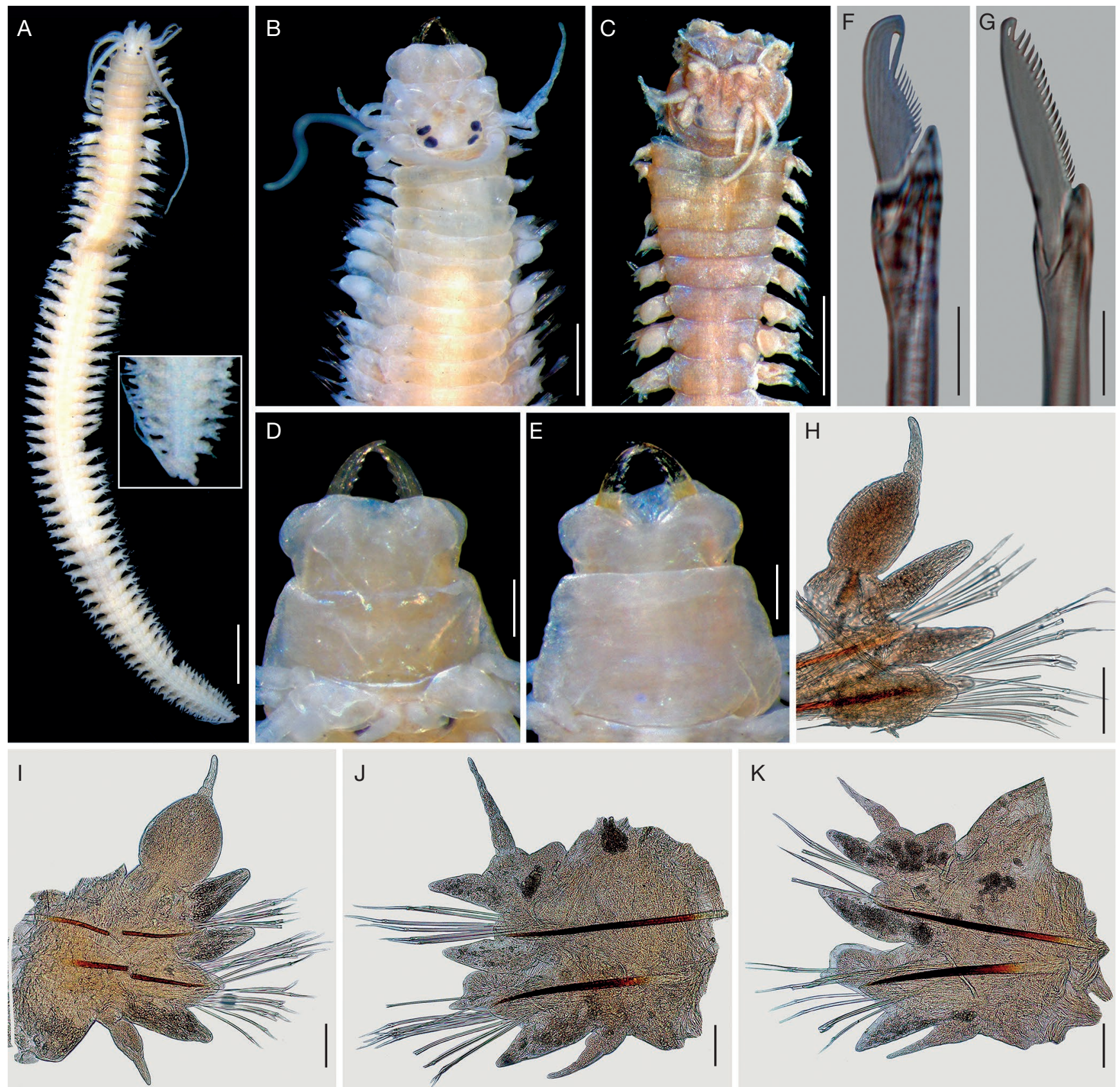

FIG. 2. - Sinonereis heteropoda Wu \& Sun, 1979: A, G, holotype (MBMCAS A-36); B-E, H-K, paratype (MBMCAS A-37); F paratype (MBMCAS A-39): A, whole specimen, dorsal view (insert: posterior end, dorsal view); B, C, anterior end, dorsal view; D, pharynx, dorsal view; E, same, ventral view; F, supra-acicular heterogomph falciger, chaetiger 5; G, sub-acicular heterogomph falciger, chaetiger 44; $\mathbf{H}$, parapodium 5, left parapodium (neuropodial ventral ligule and ventral cirri missing); I, chaetiger 6, left parapodium; J, chaetiger 23, right parapodium; K, chaetiger 35, right parapodium. Scale bars: A, 1 mm; B, C, 0.5 mm; D, E, 0.2 mm; $\mathrm{F}, \mathrm{G}, 10 \mu \mathrm{m} ; \mathrm{H}-\mathrm{K}, 0.1 \mathrm{~mm}$.

In chaetiger 7 (Fig. 3I), dorsal cirrus cirriform, 0.8 times as long as notopodial dorsal ligule. Notopodial dorsal ligule subconical, as long as notopodial ventral ligule; prechaetal lobe rounded, small; notopodial ventral ligule subconical, 1.5 times length of neuroacicular ligule. Neuroacicular ligule subconical, as long as neuropodial ventral ligule; postchaetal lobe digitate, as long as neuroacicular ligule; neuropodial ventral ligule subconical. Ventral cirrus cirriform, 0.6 times as long as neuropodial ventral ligule.
In chaetigers 19 and 39 (Fig. 3J-K), dorsal cirrus cirriform, 0.8 times as long as notopodial dorsal ligule. Notopodial dorsal ligule subconical, 0.8 times as long as notopodial ventral ligule; prechaetal lobe rounded, small; notopodial ventral ligule subconical, twice as long as neuroacicular ligule. Neuroacicular ligule subconical, 0.8 as long as neuropodial ventral ligule; postchaetal lobe digitate, as long as neuroacicular ligule; neuropodial ventral ligule subconical. Ventral cirrus cirriform, half as long as neuropodial ventral ligule. 

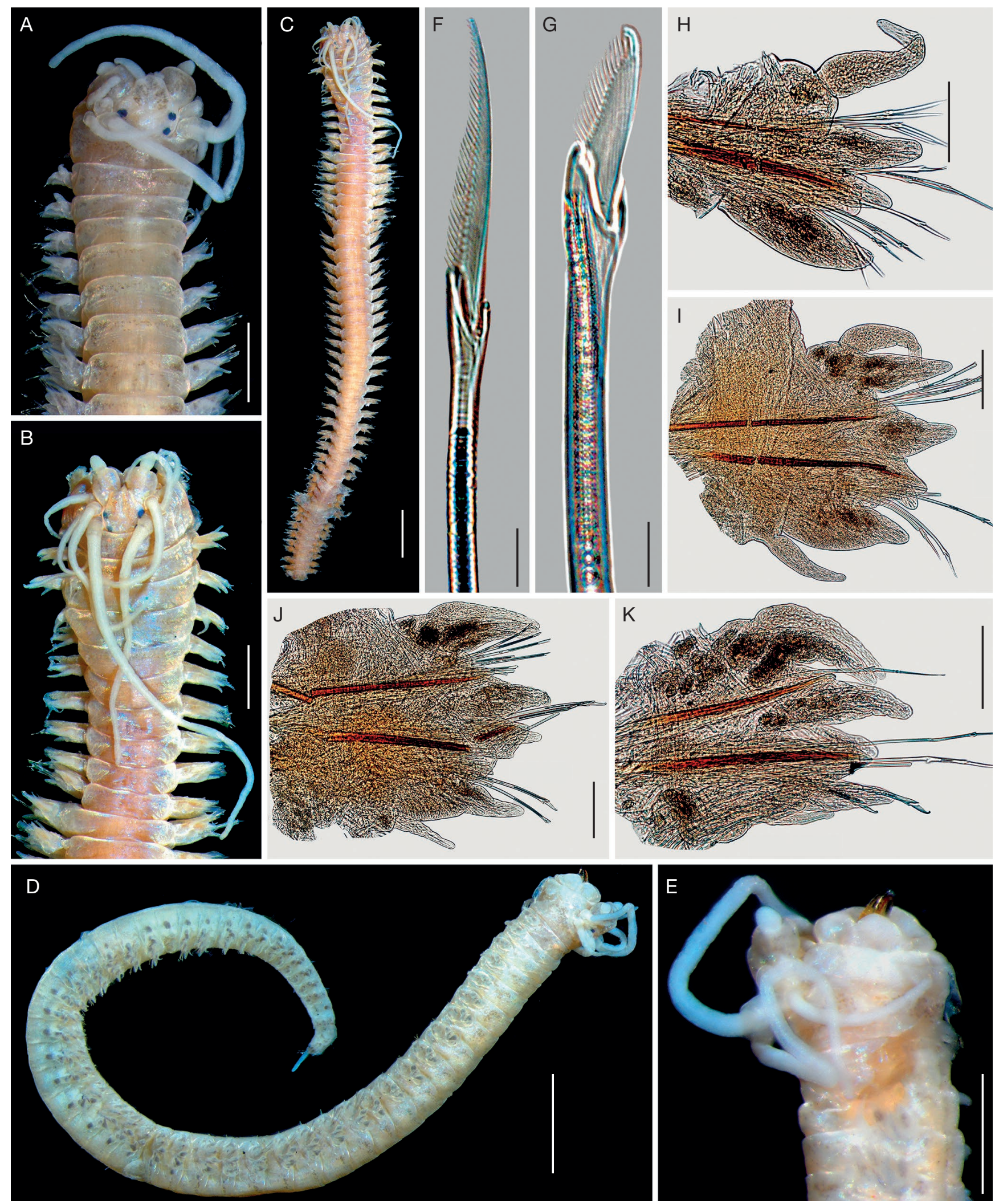

FlG. 3. - Nicon sinica Wu \& Sun, 1979: A, D-K, holotype (MBMCAS A-39); B, C, paratype (MBMCAS A-41): A, B, anterior end, dorsal view; C, whole specimen, dorsal view; D, whole specimen, lateral view; E, anterior end, lateral view; F, sub-acicular heterogomph spiniger, chaetiger 19; G, sub-acicular heterogomph falciger, chaetiger 19; H, chaetiger 3, left parapodium (ventral cirrus missing); I, chaetiger 7, left parapodium; J, chaetiger 19, left parapodium; K, chaetiger 39, left parapodium. Scale bars: A, B, E, $0.5 \mathrm{~mm}$; C, D, $1 \mathrm{~mm} ; \mathrm{F}, \mathrm{G}, 10 \mu \mathrm{m} ; \mathrm{H}-\mathrm{K}, 0.1 \mathrm{~mm}$. 


\section{Chaetae}

Notochaetae homogomph spinigers. Neurochaetae homogomph spinigers and heterogomph falcigers in supra-acicular fascicles; heterogomph spinigers and falcigers in sub-acicular fascicles.

Notopodial and neuropodial homogomph spinigers pectinate, teeth decreasing in size toward distal end; neuropodial heterogomph spiniger pectinate, teeth decreasing in size toward distal end, blade shorter than homogomph ones (Fig. 3F). Neuropodial heterogomph falcigers pectinate, teeth minute, distal tooth stout, incurved, with a distal tendon, increasing in size toward posterior chaetigers (Fig. 3G); both supra-and sub-acicular falcigers similar.

\section{Posterior end}

Pygidium tripartite; anal cirri cirriform (one missing in holotype), as long as last four chaetigers (Fig. 3D).

\section{REMARKS}

The examination of the type material revealed a high resemblance between Sinonereis heteropoda and Nicon sinica, mainly in the long anterior cirri, lack of pharyngeal ornamentation, and quite similar parapodial and chaetal morphology, such as the unusual start of the notopodial dorsal ligules from chaetiger 4 , as well as the progressive change of the blade shape in neuropodial falcigers. Wu \& Sun (1979) likely overlooked these high similarities because they focused on the modification of dorsal cirri in chaetigers 5-7 in $S$. heteropoda, which were absent in the epitokes of Nicon species described in their study, N. maculata and N. moniloceras (Wu \& Sun 1979). The examined material differs slightly from those of Miura (1990) mainly in the size of the cirrophores of dorsal cirri in chaetigers 5-7, and the size of the lamellae in natatory chaetigers, particularly in those joined to the ventral cirri. This difference might reflect changes during the process of transformation.

Núnez et al. (2000) reported Nicon sinica from Cape Breton Canyon, Cantabrian Sea, at 917-954 m depth and compared their specimens with those described from Japan, and later Núñez (2004) identified the specimens as Sinonereis heteropoda. Núnez et al. (2000) highlighted the lack of pigmentation and higher amount of notopodial homogomph spinigers (23-52) in chaetiger 10, whereas the Japanese specimens have pigmentation and a lower amount of such spinigers (9-15) (Núñez et al. 2000: 32). There are additional differences: in Chinese specimens the posterodorsal pair of anterior cirri reach chaetiger 14 , in chaetiger 10 both notopodial dorsal and ventral ligules are subequal and the ventral cirrus is half as long as neuropodial ventral ligule; whereas in the specimens from Cape Breton Canyon the posterodorsal pair of anterior cirri reach chaetiger 6 , in chaetiger 10 notopodial dorsal ligule is shorter than notopodial ventral one and the ventral cirrus is longer than neuropodial ventral ligule. On the other hand, Gillet \& Dauvin (2000) reported Sinonereis sp. in the vicinity of Hyères Seamount at 480-705 m depth in bioclastic sand, sponges and gravel, but they did not include any description or justification. Whether the above two records belong to Sinonereis requires a further study to elucidate their status.

\section{DISCUSSION}

In this contribution, we confirm the proposal of Miura (1990) that the two species belong to different stages of a single species, i.e., $S$. heteropoda and $N$. sinica are described based on epitokes and atokes, respectively. The well-defined sexual dimorphism is also emphasized that not only atokes but also females have no heteronereid transformation.

Further, this revision of the type material supports the synonymy of Sinonereis heteropoda and Nicon sinica, but we consider Sinonereis as a separate genus, because epitokal modification is definitely different between Nicon and Sinonereis. The main differences are that epitokes of Nicon species have no napiform dorsal cirri in chaetigers 5-7, and notopodial dorsal ligules start from chaetiger 3 . The genera can also be separated by some other characters as shown in Table 1. For instance, heteronereis of $N$. aestuarensis Knox, 1951 has both upper and lower lamellae of dorsal cirri and a lamella below the notopodial dorsal ligule (Knox 1951), which are all absent in $S$. heteropoda. Parapodia of natatory region have only a ventral lamellar process in $N$. maculata Kinberg, 1865 but four modified processes are present in $S$. heteropoda. Natatory chaetae are present in $N$. moniloceras (Hartman, 1940) but absent in $S$. heteropoda (Hartman 1940; Wu \& Sun 1979).

Wu \& Sun (1979: 96) compared Sinonereis with Leptonereis Kinberg, 1865 because the expanded 'shape of the dorsal cirri' and bare pharynx (Kinberg 1865), but they regarded both genera as independent because in Leptonereis such structures are in the posterior chaetigers, whereas in Sinonereis they are in the anterior chaetigers. Wu et al. (1985) noted that the expanded dorsal cirri in Leptonereis species are actually the notopodial dorsal ligules (Hartman 1945) and added the lack of neuropodial postchaetal lobes in Leptonereis and present in Sinonereis, likely they referred to ventral lamellae present in natatory chaetigers of Sinonereis epitokes but absent in the holotype of L. laevis after it consists of an atoke specimen (Hartman 1948). Nevertheless, the expanded notopodial ligules in posterior chaetigers are also absent in the atokes of $S$. heteropoda, ensuring its separation from $L$. laevis.

The genus Rullierinereis Pettibone, 1971 is also closely similar to Sinonereis after the bare pharynx and smooth tentacular cirri but a set of both atokous and epitokous features ensure their separation. Atokes of Rullierinereis species have notopodial homogomph falcigers and the notopodial dorsal ligules decrease in size and even disappear toward posterior chaetigers, features absent in atokes of Sinonereis species; further, atokes of Sinonereis have prechaetal notopodial lobes which are absent in Rullierinereis species (Pettibone 1971). Moreover, epitokes of Rullierinereis species have lower lamellae in dorsal cirri, natatory chaetae, and the females transform into heteronereis, whereas all these features are absent in epitokes of Sinonereis species; also, Sinonereis male epitokes have napiform dorsal cirri in chaetigers 5-7, feature absent in Rullierinereis male epitokes (Table 1) (Pettibone 1971). Sinonereis closely re- 
TABLE 1. - Comparison of some morphological features in epitokes among genera Kainonereis Chamberlin, 1919, Nicon Kinberg, 1865, Rullierinereis Pettibone, 1971 and Sinonereis Wu \& Sun, 1979. Based on Conde-Vela et al. (2018), Knox (1951), Miura (1990), Pettibone (1971), and Wu et al. (1985).

\begin{tabular}{|c|c|c|c|c|}
\hline Character & Kainonereis & Nicon & Rullierinereis & Sinonereis \\
\hline \multicolumn{5}{|l|}{ Body features } \\
\hline Tentacular cirri & true articulated throughout & $\begin{array}{l}\text { smooth throughout or } \\
\text { distally articulated }\end{array}$ & smooth throughout & smooth throughout \\
\hline Number of body regions & 2 in both sexes & 2 or 3 & 2 in males, 3 in females & 2 in both sexes \\
\hline $\begin{array}{l}\text { Subregions in non- } \\
\text { natatory region }\end{array}$ & 3 & 2 & 2 & 3 \\
\hline $\begin{array}{l}\text { Heteronereid transforma- } \\
\text { tion in females }\end{array}$ & present & present or absent & present & absent \\
\hline \multicolumn{5}{|c|}{ Non-natatory region features } \\
\hline $\begin{array}{l}\text { Start of notopodial } \\
\text { dorsal ligules } \\
\text { Shape of dorsal cirri in } \\
\text { chaetigers 5-7 }\end{array}$ & $\begin{array}{l}\text { chaetiger } 3 \text { in atokes and } \\
\text { females; chaetiger } 4 \text { in males } \\
\text { elytriform }\end{array}$ & $\begin{array}{l}\text { chaetiger } 3 \text { in both } \\
\text { atokes and epitokes } \\
\text { fusiform }\end{array}$ & $\begin{array}{l}\text { chaetiger } 3 \text { in both atokes } \\
\text { and epitokes } \\
\text { fusiform }\end{array}$ & $\begin{array}{l}\text { chaetiger } 4 \text { in both atokes } \\
\text { and epitokes } \\
\text { napiform }\end{array}$ \\
\hline $\begin{array}{l}\text { Notopodial falcigers in } \\
\text { chaetigers } 5-7\end{array}$ & present in males only & absent & absent & absent \\
\hline \multicolumn{5}{|l|}{ Natatory region features } \\
\hline Dorsal lamella & present & absent & absent & present \\
\hline $\begin{array}{l}\text { Lower lamella of dorsal } \\
\text { cirrus }\end{array}$ & present & present & absent & absent \\
\hline $\begin{array}{l}\text { Upper lamella of dorsal } \\
\text { cirrus }\end{array}$ & present & present & present & absent \\
\hline $\begin{array}{l}\text { Crenulations in dorsal } \\
\text { cirri of males }\end{array}$ & absent & absent & present & absent \\
\hline $\begin{array}{l}\text { Lamella below notopodial } \\
\text { ventral ligule }\end{array}$ & absent & present & present & absent \\
\hline Natatory chaetae & present & present or absent & present & absent \\
\hline $\begin{array}{l}\text { Pygidium with anal } \\
\text { papillae }\end{array}$ & absent & absent & present & absent \\
\hline
\end{tabular}

sembles Kainonereis Chamberlin, 1919 because they have a similar modification of dorsal cirri in chaetigers 5-7 (Chamberlin 1919). However, in Kainonereis the dorsal cirrophores are clearly modified into elytriform structures, namely dorsal discs (Conde-Vela et al. 2018), whilst in Sinonereis corresponding cirrophores are globose or ovoid. Moreover, males of Kainonereis have anterior cirri truly articulated, upper and lower lamellae of dorsal cirri, notopodial homogomph falcigers in first seven chaetigers and well-developed natatory chaetae, all of which are absent in males of Sinonereis (Table 1). In addition, females have similar heteronereid modifications as males in Kainonereis (only lacking the notopodial homogomph falcigers in first seven chaetigers), whereas in Sinonereis females display no heteronereid transformation. The start of notopodial dorsal ligules from chaetiger 4 in males and chaetiger 3 in females is also remarkable in Kainonereis epitokes, whereas in Sinonereis they start from chaetiger 4 in both males and females.

As an additional confirmation of how problematic it is matching atokes and epitokes, we must recall that the atokes of Sinonereis, and atoke and epitokes of some Kainonereis species, were regarded as different species in Nicon because of the simple definitions of these genera. However, the differences among the epitoke specimens belonging to the genera Kainonereis, Nicon and Sinonereis mentioned above allow us to recognize Sinonereis as a distinct, valid genus.
The lack of heteronereid transformations in females has been reported for other nereidid species. Males of Alitta virens (Sars, 1835) undergo epitoky and the heteronereis spawn in front of the galleries of the unmodified females, which trap the sperm by moving the water inside, and after release the oocytes and the eggs and the benthic larvae which are retained inside (Bass \& Brafield 1972). Also, there are metabolic differences between males and females because of the energetic requirements for swimming (Chatelain et al. 2008). Similarly, females of Sinonereis heteropoda could remain inside their galleries in the mud and the fecundation could occur inside, and therefore a restricted distribution is expected. Future studies about the ecology, physiology and reproduction of this species are encouraged to elucidate such issues.

\section{Acknowledgements}

We thank Sergio I. Salazar-Vallejo for reading an early draft and made valuable suggestions. Also, we would like to thank the two reviewers, Torkild Bakken and Robin Wilson, for their suggestions resulting in significant improvements. XW thanks the support by the National Natural Science Foundation of China (No. 31601842). VMCV is supported by a scholarship from CONACyT (No. 586685) and additional funds from Fundación Telmex (No. 142040601). 


\section{REFERENCES}

BAKKen T. \& Wilson R. S. 2005. - Phylogeny of nereidids (Polychaeta, Nereididae) with paragnaths. Zoologica Scripta 34 (5): 507-547. https://doi.org/10.1111/j.1463-6409.2005.00200.x

BASS N. R. \& BRAFIELD A. E. 1972. - The life-cycle of the polychaete Nereis virens. Journal of the Marine Biological Association of the United Kingdom 52 (03): 701-726. https://doi.org/10.1017/ S0025315400021664

Chamberlin R. V. 1919. - The Annelida Polychaeta of the Albatross Tropical Pacific Expedition, 1891-1905. Memoirs of the Museum of Comparative Zoology at Harvard College 48: 1-514.

Chatelain É. H., Breton S., Lemieux H. \& Blier P. U. 2008. Epitoky in Nereis (Neanthes) virens (Polychaeta: Nereididae): A story about sex and death. Comparative Biochemistry and Physiology, Part B 149 (1): 202-208. https://doi.org/10.1016/j. cbpb.2007.09.006

CLARK R. B. 1961. - The origin and formation of the heteronereis. Biological Reviews 36 (2): 199-236. https://doi.org/10.1111 j.146918 X.1961 tb01584 x.

Conde-Vela V. M., Wu X. \& Salazar-Vallejo S. I. 2018. Reevaluation and new species of Kainonereis Chamberlin, 1919 (Annelida: Polychaeta: Nereididae). Zoological Studies 57 (6): 1-24. https://doi.org/10.6620/ZS.2018.57-06

FiTZHUGH K. 1987. - Phylogenetic relationships within the Nereididae (Polychaeta): implications at the subfamily level. Bulletin of the Biological Society of Washington 7: 174-183.

Gillet P. \& DAUVIN J.-C. 2000. - Polychaetes from the Atlantic seamounts of the southern Azores: biogeographical distribution and reproductive patterns. Journal of the Marine Biological Association of the UK 80: 1019-1029.

HaRTMAN O. 1940. — Polychaetous annelids. Part II. Chrysopetalidae to Goniadidae. Allan Hancock Pacific Expeditions 7 (3): 173-287.

HARTMAn O. 1945. - The marine annelids of North Carolina. Duke University Marine Station Bulletin 2: 1-51.

HARTMAN O. 1948. - The marine annelids erected by Kinberg with notes on some other types in the Swedish State Museum. Arkiv för Zoologi 42A (1): 1-137.
Kinberg J. G. H. 1865. — Annulata Nova (Nereidum Dispositio Nova. Leonnatidea, Nereidea, Aretidea, Pisenoidea, Niconidea). Öfversigt af Kongelige Vetenskaps-Akademiens Förhandlingar 22 (2): 167-179.

KNox G. A. 1951. - The polychaetous annelids of Banks Peninsula. Part I. Nereidae. Records of the Canterbury Museum 5 (5): 213-229.

Miura T. 1990. - Nicon sinica Wu and Sun, 1979, a newly recorded polychaete from Japan. Benthos Research 38: 11-17.

NúNEZ J. 2004. - Familia Nereididae, in Ramos M. Á. (ed.), Fauna Ibérica. Museo Nacional de Ciencias Naturales, CSIC, Madrid: 293-390.

NúNÉz J., AguirreZabalaga F. \& Ceberio A. 2000. — Species of Nereididae from the Capbreton Canyon (Bay of Biscay, Northeast Atlantic). Bulletin of Marine Science 67 (1): 25-37.

PAIK E.-I. 1997. — New record of Nicon sinica (Polychaeta: Nereidae) in Yellow Sea, Korea. Journal of the Korean Fisheries Society 31: 152-157.

Pettibone M. H. 1971. - Revision of some species referred to Leptonereis, Nicon, and Laeonereis (Polychaeta: Nereididae). Smithsonian Contributions to Zoology 104: 1-53.

Santos C. S. G., Pleijel F., Lana P. D. C. \& Rouse G. W. 2005. Phylogenetic relationships within Nereididae (Annelida: Polychaeta). Invertebrate Systematics 19 (6): 557-576. https://doi. org/10.1071/IS05001

Schroeder P. C. \& Hermans C. O. 1975. - Annelida: Polychaeta, in GIESE A. C. \& PEARSE J. S. (eds), Reproduction of Marine Invertebrates. Volume III: Annelids and Echiurans. Academic Press, London: 1-213.

Sun R. \& YANG D. J. 2004. - Annelida. Polychaeta II. Nereidida (=Nereimorpha). Nereididae, Syllidae, Hesionidae, Pilargidae, Nephtyidae, in HuO C. \& ZHAO G. (eds), Fauna Sinica, Invertebrata, Vol. 33. Beijing: $520 \mathrm{p}$.

Wu B.-L. \& Sun R. 1979. - Revision of the genera Nicon and Rullierinereis, with description of a new genus Sinonereis (Polychaeta: Nereidae). Oceanic Selections 2 (2): 95-112.

Wu B.-L., Sun R. \& YANG D. J. 1985. - Nereidae (Polychaetous annelids) of the Chinese coast. China Ocean Press, Beijing, $234 \mathrm{p}$. 